\title{
Overflow diarrhea and acute kidney injury as a presentation of fecal impaction that led to obstructive uropathy
}

\begin{abstract}
Fecal impaction is a known complication of chronic constipation and is particularly bothersome in the elderly population. Common complications of fecal impaction include hemorrhoids, megacolon, overflow diarrhea, and obstructive uropathy among others. Many case reports have been reported with fecal impaction and obstructive uropathy though none have reported overflow diarrhea as a presentation. In this case report, we present an elderly male who came in with overflow diarrhea and acute kidney injury that resulted from fecal impaction that caused obstructive uropathy. He was managed with catharsis and early recognition of the condition led to a good outcome. Recognition and management of fecal impaction can be challenging especially in patients who present with diarrhea. We, therefore, outline and discuss the importance of recognition of overflow diarrhea as a complication of fecal impaction and the management of such patients.
\end{abstract}

Volume II Issue 3 - 202I

\author{
Dhara Dave, llya Ivyanskiy,Tarek Naguib \\ Department of Internal Medicine, Texas Tech University Health \\ Sciences Center, USA
}

Correspondence: Dhara Dave, Department of Internal Medicine, Texas Tech University Health Sciences Center, USA, Email dhara.dave@ttuhsc.edu

Received: May 10, 2021 | Published: May 31, 2021

\section{Introduction}

Fecal impaction complicates as many as $2 \%$ of persons with long-standing constipation and may be associated with dietary (low fiber, low carbohydrate, high protein diets, insufficient fluid intake), anatomic, pharmacologic, metabolic (such as hypokalemia and hypocalcemia), and neurogenic etiologies. When adjusted for detection bias, fecal impaction (OR 3.2) was found to be only second to Hirschsprung disease in being associated with constipation. ${ }^{1}$ Nursing home residents, patients with psychiatric, neurologic, and cardiac diseases, patients taking medications impairing colonic motility are at particular risk. ${ }^{2}$ Several factors may contribute to the development of fecal impaction in older adults including impaired cognitive function, immobility, rectal hyposensitivity, and inadequate intake of fluids. ${ }^{2}$

One retrospective article of patients who presented with fecal impaction at Beth Israel Deaconess Medical Center reported that at least $54.8 \%$ of these patients were taking at least one commonly prescribed constipation causing medication. ${ }^{3}$ In another retrospective study of 130 patients who presented to a tertiary center in Beirut with fecal impaction reported $75.3 \%$ had at least one of the following concurrent conditions: heart disease, neurological disease, diabetes, or being bedridden. In over two-thirds of these patients, the site of impaction was the rectum. ${ }^{4}$

Fecal impaction usually occurs in the rectum and the distal colon and can cause an overflow of liquid stool around the impacted fecal mass. It can be further complicated by systemic inflammatory response syndrome, stercoral ulceration with bowel perforation, megacolon, hemorrhoids, and rectal bleeding. ${ }^{1,2,4,8}$

Fecal incontinence is a common consequence of fecal impaction and is thought to be a result of a multitude of factors including a more obtuse anorectal angle, low anal pressures, mobility, pelvic floor muscle integrity, and impaired anorectal sensation. ${ }^{5}$ Overflow diarrhea is frequently misdiagnosed and treated with antidiarrheal medications. The mainstay of treatment of overflow diarrhea is laxatives, particularly enemas; manual disimpaction and surgical consultation in cases of severe and refractory constipation may be warranted. Lubiprostone, a chloride channel activator that increases intestinal fluid secretion and improves fecal transit, can also be used if other laxatives are ineffective.

Obstructive uropathy is also a well-established complication of fecal impaction. There are two age peaks in the incidence of fecal impaction with obstructive uropathy. ${ }^{6}$

Children and adolescents are more susceptible to obstructive uropathy from fecal impaction due to the higher intra-abdominal location of the bladder and loose connective tissue providing more mobility of intra-abdominal organs predisposing to compression by adjacent structures.

The other group is patients predominantly over 65 years old with multiple risk factors including diabetes mellitus, cerebrovascular disease, dementia, hypothyroidism, depression, or opioid use. To be noticed, the female gender doesn't seem to be protected by uterus position as has been noted by relatively equal gender distribution in previous reports. ${ }^{7,8}$

The most likely underlying mechanism of obstructive uropathy in fecal impaction is the elevation of the floor of the bladder and posterior urethra obstructing the bladder outlet, the most common level of obstruction being urethra or urethral-vesical junction. ${ }^{9-11}$

We came across 23 case reports of fecal impaction that were associated in one way or the other with hydronephrosis and obstructive uropathy and 15 of these were in patients aged over 65 years. In all these cases, the patients presented with at least a few weeks of constipation and failure to defecate.

During our literature search, we did not come across any case where a patient with fecal impaction presented with overflow diarrhea and acute kidney injury associated with acute urinary retention.

\section{Case report}

Today we present an 82-year-old Male with PMH of diabetes, hypertension, coronary artery disease, paroxysmal atrial fibrillation, 
sick sinus syndrome with a pacemaker, prostate cancer $\mathrm{s} / \mathrm{p}$ radiation, and myelodysplastic syndrome who came in with a 4-week history of non-bloody watery diarrhea (up to 8 to 10 episodes per day) with associated fecal incontinence, abdominal bloating and generalised pain. He did report a long-standing history of constipation before this. No history of fevers or recent use of antibiotics or new medications.

His home medications included azacitidine, leuprolide, apixaban, simvastatin, metformin, glargine, and alogliptin.

On exam, he was found to have vitals within normal limits and he was a frail elderly gentleman with diffuse abdominal distention with generalised tenderness worse over the suprapubic area with distended bladder. A foley catheter was placed with drainage of over 1 liter of urine.

Rectal exam showed no skin tags or external hemorrhoids. Normal rectal tone and brown loose stool in the rectal vault.

Labs showed normal white cell count and mild anemia (hemoglobin $11 \mathrm{~g} / \mathrm{dL}$ ) with elevated creatinine at $1.5 \mathrm{mg} / \mathrm{dL}$. Electrolytes within normal limits except hypokalemia of $3.3 \mathrm{mEq}$.

Prostate specific antigen (PSA) level was within normal limits.

He was initially managed conservatively with IV fluid resuscitation.

Stool analysis showed no evidence of ova or parasites and was negative for leukocytes.

Stool culture grew no organisms and was negative for Clostridium difficile and shiga toxin.

Computed Tomography (CT) scan of the abdomen without contrast done to evaluate for obstructive uropathy showed large stool burden in the distal colon and rectum with mild wall thickening and bilateral severe hydroureteronephrosis.

The patient was managed conservatively with laxatives and intravenous hydration.

A week after presentation creatinine had improved to the baseline of $1.0 \mathrm{mg} / \mathrm{dL}$ and repeated CT scan showed significantly reduced stool burden and improving wall thickness of the rectum, colon, and urinary bladder as well as improving hydronephrosis.

The urinary catheter was removed and the patient was able to void completely on his own. He was discharged on laxatives and home medications.
On a subsequent admission one month later for a different diagnosis, the patient was found to have worsening stool burden in the rectum with worsening bilateral hydronephrosis. He continued taking laxatives. After two more admissions for different diagnoses, the patient and his family decided to go with comfort care.

\section{Discussion}

Our patient had multiple risk factors for fecal impaction including age, immobility, diabetes, and medications. Azacitidine and Leuprolide can cause constipation in $33.6 \%$ to $50.3 \%$ and $9.9 \%$ respectively. ${ }^{12,13}$ It was thought that he likely had chronic constipation leading to fecal impaction which led to overflow diarrhea and was complicated by acute urinary obstruction due to obstruction at the level of the bladder. Despite having been found to have mildly low potassium levels, there was no improvement in his condition after correction of the potassium levels, leading us to think of other causes of constipation. Our patient's urinary obstruction was not due to prostate enlargement as is the case in many adult males given that he had had prostate surgery, the prostate was not enlarged on rectal exam, and PSA was within normal limits.

With catharsis, his stool burden reduced and hydronephrosis improved. Early recognition of the acute retention and hydronephrosis and management of the impaction with gentle catharsis led to a good outcome.

In contrast to our patient who had overflow diarrhea as a result of constipation which was complicated by acute obstructive uropathy and acute kidney injury, there was one case report of a patient with an over distended bladder that caused extrinsic bowel compression that led to chronic diarrhea which improved after clean intermittent catheterization.

Also noted from our literature review of other cases of urinary obstruction and fecal impaction, which are summarized in the Table 1 below, was that most patients were above the age of 65 , and a majority of these had dementia or psychosis. Almost all patients did well with laxatives and manual removal though there were two deaths; one was in a patient with a ruptured bladder due to obstruction and the other was in a septic patient.

It is important to consider fecal impaction as a cause of incontinence especially in elderly patients. Careful history and physical examination can raise suspicion of the diagnosis while imaging is essential in confirming it. Treatment should be tailored to the underlying mechanism and needs of the patients.

Table I Summarized table of case reports with fecal impaction and urinary obstruction

\begin{tabular}{|c|c|c|c|c|c|c|c|}
\hline Reference & Age & Sex & Associated illnesses & Presentation & Level of obstruction & Treatment & Outcome \\
\hline 14 & 19 & Male & Paraplegia & $\begin{array}{l}\text { Urinary Tract } \\
\text { infection, Acute Renal } \\
\text { Failure }\end{array}$ & Bilateral ureters & Unclear & Well \\
\hline 15 & 21 & Female & Myelomeningocele & $\begin{array}{l}\text { Routine Intravenous } \\
\text { Pyelogram }\end{array}$ & $\begin{array}{l}\text { Right } \\
\text { hydronephrosis }\end{array}$ & Manual removal & Well \\
\hline 16 & 23 & Male & Mental retardation & Abdominal pain & Bladder neck & $\begin{array}{l}\text { Manual removal, } \\
\text { enema, colostomy }\end{array}$ & Well \\
\hline 17 & 30 & Male & Hirchsprung's disease & Acute urine retention & Right hydronephrosis & ?manual removal & Well \\
\hline 18 & 50 & Male & Neurogenic bladder & $\begin{array}{l}\text { Routine Intravenous } \\
\text { Pyelogram }\end{array}$ & Left hydronephrosis & $\begin{array}{l}\text { Manual removal, } \\
\text { enema, laxative }\end{array}$ & Well \\
\hline 11 & 55 & Male & Schizophrenia & Cachexia & Urethra & - & Died \\
\hline
\end{tabular}




\begin{tabular}{|c|c|c|c|c|c|c|c|}
\hline Reference & Age & Sex & Associated illnesses & Presentation & Level of obstruction & Treatment & Outcome \\
\hline 19 & 59 & Male & Unknown & $\begin{array}{l}\text { Urinary Tract } \\
\text { infection }\end{array}$ & Bilateral ureter & enema & Well \\
\hline 20 & 60 & Female & $\begin{array}{l}\text { Depression, post- } \\
\text { traumatic pelvic injury }\end{array}$ & Anuresis & $\begin{array}{l}\text { Bladder neck; Right } \\
\text { ureter }\end{array}$ & $\begin{array}{l}\text { Enema, Manual } \\
\text { removal }\end{array}$ & Well \\
\hline 21 & 63 & Female & $\begin{array}{l}\text { History of hemorrhagic } \\
\text { stroke }\end{array}$ & Constipation & $\begin{array}{l}\text { Bilateral } \\
\text { hydronephrosis }\end{array}$ & $\begin{array}{l}\text { Colonoscopic } \\
\text { irrigation, manual } \\
\text { removal (failed } \\
\text { laxatives and enema) }\end{array}$ & Well \\
\hline 22 & 65 & Female & None & Anuresis & - & Manual removal & Well \\
\hline 23 & 67 & Male & None & Iliac vein occlusion & Left ureter & $\begin{array}{l}\text { lleostomy } \\
\text { (failed laxatives) }\end{array}$ & Well \\
\hline 24 & 70 & Male & Cardio-vascular disease & Diarrhea & Left hydronephrosis & Manual removal & Well \\
\hline 25 & 71 & Male & $\begin{array}{l}\text { Diabetes Mellitus, } \\
\text { Cardio-vascular disease }\end{array}$ & $\begin{array}{l}\text { Urinary Tract } \\
\text { infection, Acute Renal } \\
\text { Failure }\end{array}$ & Bilateral ureters & Manual removal & Well \\
\hline 26 & 71 & Male & Diabetes Mellitus & Abdominal pain & Right hydronephrosis & Manual removal & Well \\
\hline 27 & 73 & Female & $\begin{array}{l}\text { Cerebral Vascular } \\
\text { Disease }\end{array}$ & Anuresis & - & Enemal, rectal lavage & Well \\
\hline 28 & 74 & Female & $\begin{array}{l}\text { Diabetes Mellitus, } \\
\text { Cardio-vascular disease }\end{array}$ & $\begin{array}{l}\text { Urinary Tract } \\
\text { infection, Acute Renal } \\
\text { Failure }\end{array}$ & Right ureter & $\begin{array}{l}\text { Manual removal, } \\
\text { enema }\end{array}$ & Well \\
\hline 29 & 75 & Female & Dementia & $\begin{array}{l}\text { Urinary Tract } \\
\text { infection }\end{array}$ & Right ureter & Enema & Well \\
\hline 30 & 81 & Female & $\begin{array}{l}\text { Dementia, sigmoid } \\
\text { diverticulosis }\end{array}$ & $\begin{array}{l}\text { Urinary Tract } \\
\text { infection }\end{array}$ & $\begin{array}{l}\text { Bilateral } \\
\text { hydronephrosis }\end{array}$ & $\begin{array}{l}\text { Manual removal, } \\
\text { rectal lavage } \\
\text { (ineffective laxatives) }\end{array}$ & Well \\
\hline 11 & 81 & Female & Psychosis & Infective endocarditis & Urethra & - & Died \\
\hline 27 & 82 & Female & unknown & Anuresis & - & - & Well \\
\hline Our case & 82 & Male & $\begin{array}{l}\text { DM, prostate cancer, } \\
\text { MDS on azacitidine }\end{array}$ & $\begin{array}{l}\text { Diarrhea, Acute Renal } \\
\text { Failure }\end{array}$ & $\begin{array}{l}\text { Bilateral } \\
\text { hydronephrosis }\end{array}$ & Laxatives, enema & Well \\
\hline 31 & 84 & Male & opioids & Lower limb ischemia & - & $\begin{array}{l}\text { Manual removal, } \\
\text { rectal lavage }\end{array}$ & Well \\
\hline 32 & 85 & Female & hypothyroidism & $\begin{array}{l}\text { Acute Renal Failure, } \\
\text { lower limb edema }\end{array}$ & $\begin{array}{l}\text { Bilateral } \\
\text { hydronephrosis }\end{array}$ & $\begin{array}{l}\text { Manual removal, } \\
\text { enema }\end{array}$ & Well \\
\hline 29 & 88 & Female & dementia & $\begin{array}{l}\text { Urinary Tract } \\
\text { infection, Acute Renal } \\
\text { Failure, shock }\end{array}$ & Right hydronephrosis & - & died \\
\hline 33 & 90 & Female & $\begin{array}{l}\text { DM, dementia, } \\
\text { neurogenic bladder }\end{array}$ & $\begin{array}{l}\text { Chronic constipation, } \\
\text { recurrent } \\
\text { Urinary Tract } \\
\text { infections, loss of } \\
\text { appetite, fever }\end{array}$ & Right ureter & $\begin{array}{l}\text { Manual disimpaction, } \\
\text { enema, laxatives }\end{array}$ & Well \\
\hline
\end{tabular}

\section{Conclusion}

Treatment of overflow diarrhea is counter-intuitive in that it requires relief of the underlying impaction with laxatives rather than antidiarrheal medications which would make the condition worse. Morbidity and mortality of fecal impaction is particularly high in the elderly hence patients with chronic constipation warrant aggressive measures to relieve it.

\section{Conflicts of interest}

The author declares no conflict of interest.

\section{Acknowledgments}

None.

\section{Funding}

None.

\section{References}

1. Arora G, Mannalithara A, Mithal A, et al. Concurrent conditions in patients with chronic constipation: a population-based study. PLoS One. 2012;7(10):e42910. 
2. Kolar GJ, Tabibian JH, Mangan TF. 20-year history of diarrhea with intermittent constipation. Am Fam Physician. 2014;89(9):739-740.

3. Sommers T, Petersen T, Singh P, et al. Significant Morbidity and Mortality Associated with Fecal Impaction in Patients Who Present to the Emergency Department. Dig Dis Sci. 2019;64(5):1320-1327.

4. Halawi HM, Maasri KA, Mourad FH, et al. Faecal impaction: in-hospital complications and their predictors in a retrospective study on 130 patients. Colorectal Dis. 2012;14(2):231-236.

5. Read NW, Abouzekry L. Why do patients with faecal impaction have faecal incontinence. Gut. 1986;27(3):283-287.

6. Rishor-Olney CR, Hinson MR. Obstructive Uropathy. 2020.

7. Barrett MJ, Macken S. Chronic constipation causing obstructive nephropathy in a delayed toddler. BMJ Case Rep. 2012 Jun 14;2012:bcr0220125902.

8. Read NW, Celik AF, Katsinelos P. Constipation and incontinence in the elderly. J Clin Gastroenterol. 1995;20(1):61-70.

9. Ravich L. Letter: Constipation: a cause of urinary tract obstruction and infection. Urology. 1976;7(2):236-237.

10. Ravich L, Lerman PH, Schell NB. Urinary retention due to fecal impaction. N Y S J Med. 1963;63: 3289-3291.

11. Lal S, Brown GN. Some unusual complications of fecal impaction. Am J Proctol. 1967;18(3):226-231.

12. Martínez-Francés A. Adverse effects of azacitidine: onset, duration, and treatment. Adv Ther. 2011;4:1-5.

13. Gallagher JS, Missmer SA, Hornstein MD, et al. Long-Term Effects of Gonadotropin-Releasing Hormone Agonists and Add-Back in Adolescent Endometriosis. J Pediatr Adolesc Gynecol. 2018;31(4):376-381.

14. Nelson RP, Brugh R. Bilateral ureteral obstruction secondary to massive fecal impaction. Urology. 1980;16(4):403-406.

15. Emmott RC, Tanagho EA. Ureteral obstruction due to fecal impaction in patient with colonic loop urinary diversion. Urology. 1980;15(5):496-497.

16. Pery M, Kaftori JK, Alon U. False uroradiologic pathology in children with urinary tract infection and fecal impaction. Child Nephrol Urol. 1988-1989;9(6):349-351

17. Davidov MI. A giant fecalith complicated by acute urinary retention, hydronephrosis and acute obstructive pyelonephritis. Urologiia. 2016;(2):109-111.

18. Delaere KP, Braam PF, Debruyne FM. Unilateral hydroureteronephrosis resolved by fecal disimpaction in a patient with neurogenic bladder. Acta Urol Belg. 1983;51(3):289-292.
19. Ben-Ami H, Roguin A. [Fecaloma-induced bilateral hydroureter]. Harefuah. 1997;132(5):371.

20. Adriazola Semino M, Ortiz Cabria R, Alonso Villalba A, et al. Fecaloma gigante como causa de incontinencia e inestabilidad vesical femenina. Aportación de un caso [Giant fecal impaction as a cause of female incontinence (Fecaloma) and bladder instability. Contribution with one case]. Actas Urol Esp. 2004;28(7):527-529.

21. Tu KC, Kuo JR. Fecaloma causing megacolon and bilateral hydronephrosis Formosan Journal of Surgery. 2020;53(2):70-73.

22. Ney C, Hyman RM. Complete urinary retention in female. Am J Surg. $1954 ; 87(1): 34-40$

23. Nguyen H, Simpson RR, Kennedy ML, et al. Idiopathic megacolon causing iliac vein occlusion and hydronephrosis. Aust $N Z J$ Surg. 2000;70(7):539-542.

24. Oestmann A. Hydronephrose bei Stuhlimpaktion [Hydronephrosis in impacted feces]. Schweiz Med Wochenschr. 1997;15;127(46):1925.

25. Claffey KB, Patton ML, Haith LR Jr, et al. Barium and fecal impaction: an unusual case of bilateral hydronephrosis. Am Surg. 1995;61(8):709-713.

26. Tan CK, Lai CC, Kan WC, et al. Hydronephrosis caused by fecal impaction. Kidney Int. 2008;73(9):1099-100.

27. Bouffioux C, de Leval J. La rétention vésicale: manifestation d'une constipation opiniâtre Bladder retention as a manifestation of persistant constipation]. Acta Urol Belg. 1975;43(1):77-83.

28. McWilliams WA, Khauli RB, Zein TA. Ureteral obstruction due to massive fecal impaction. South Med J. 1984;77(2):275-276.

29. Gonzalez F. Obstructive uropathy caused by fecal impaction: report of 2 cases and discussion. Am J Hosp Palliat Care. 2010;27(8):557-559.

30. Knobel B, Rosman P, Gewurtz G. Bilateral hydronephrosis due to fecaloma in an elderly woman. J Clin Gastroenterol. 2000;30(3):311-313.

31. Hoballah JJ, Chalmers RT, Sharp WJ, et al. Fecal impaction as a cause of acute lower limb ischemia. Am J Gastroenterol. 1995;90(11):2055-2057.

32. Yuan R, Zhao GG, Papez S, et al. Urethral obstruction and bilateral ureteral hydronephroses secondary to fecal impaction. J Clin Gastroenterol. 2000;30(3):314-316.

33. Iwata Y, Kunishi Y, Yoshie K. Obstructive uropathy caused by chronic constipation. Intern Med. 2015;54(9):1043-1047. 